\title{
ВПЛИВ ЕНДОГЕННОЇ ІНТОКСИКАЦІЇ НА РОЗВИТОК УСКЛАДНЕНЬ ПІСЛЯ ОПЕРАТИВНОГО ЛІКУВАННЯ ХВОРИХ ЗІ СПАЙКОВОЮ КИШКОВОЮ НЕПРОХІДНІСТЮ
}

\begin{abstract}
Резюме. Проблема гострої спайкової кишкової непрохідності залишається однією з найбільш актуальних та складних у сучасній абдомінальній хірургії. Серед усіх видів непрохідності спайкова непрохідність кишечника зустрічається найчастіше і складає від 40,4 до 86 \% випадків.

Мета дослідження - оцінити рівень показників ендогенної інтоксикації у хворих із спайковою кишковою непрохідністю до та після оперативного втручання та встановити їх вплив на розвиток ускладнень в післяопераційному періоді.

Матеріали і методи. У статі висвітлено результати обстеження 57 хворих із гострою спайковою кишковою непрохідністю. 3 них 26 пацієнтів прооперовано лапароскопічно, 31 - виконано лапаротомію із подальшою ліквідацією непрохідності. Проведено дослідження рівня маркерів ендогенної інтоксикації (середньомолекулярних пептидів та визначення еритроцитарного індексу інтоксикації) до операції та на 3 добу післяопераційного періоду.

Результати досліджень та їх обговорення. Встановлено, що у хворих із гострою спайковою кишковою непрохідністю значно зростає рівень маркерів ендогенної інтоксикації до операції і ступінь зростання цих показників перш за все залежить від стадії перебігу кишкової непрохідності. На 3 добу після операції виявлено незначне зниження рівня ендогенної інтоксикації, що свідчить про додаткові механізми розвитку токсикозу після оперативного втручання.

Висновки. Протягом дослідження ми не встановили значно достовірного взаємозв'язку між маркерами ендогенної інтоксикації та розвитком ускладнень у післяопераційний період. Виявлено тісний взаємозв'язок між часом відновлення моторної функції кишок та рівнем ендогенної інтоксикації, що свідчить про провідну роль кишечника у формуванні токсикозу в пацієнтів із спайковою кишковою непрохідністю.
\end{abstract}

Ключові слова: гостра спайкова кишкова непрохідність; ендогенна інтоксикація; ускладнення; післяопераційний період.

ВстУп Проблема гострої спайкової кишкової непрохідності залишається однією з найбільш актуальних та складних у сучасній абдомінальній хірургії $[2,6,7]$. Серед усіх видів непрохідності спайкова непрохідність кишечника зустрічається найчастіше і складає від 40,4 до 86 \% випадків [3]. Незважаючи на вдосконалення методів хірургічного лікування та інтенсивної терапії, гостра тонкокишкова непрохідність (ГТКН) залишається одним 3 найбільш тяжких порушень фрункції органів черевної порожнини, про що свідчать високі показники післяопераційних ускладнень і летальності $[1,7]$.

У прогресуванні перебігу спайкової кишкової непрохідності та розвитку ускладнень провідну роль відводять розвитку синдрому ендогенної інтоксикації, зумовленої комплексом метаболічних порушень, що є основною причиною розвитку поліорганної недостатності $[1,5]$.

До числа ендогенних токсичних субстанцій відносять мікробні ендотоксини, медіатори системного запалення і речовини, які накопичуються в організмі внаслідок гіперпродукції або резорбції із вогнищ тканинної деструкції, а також із затримкою виведення цих речовин унаслідок недостатності органів природної детоксикації [5].

Важливим питанням $€$ розвиток ендогенної інтоксикації не лише як наслідок основного захворювання, а й у післяопераційний період, як результат багатьох факторів, включаючи й операційну травму.

Метою дослідження було оцінити рівень показників ендогенної інтоксикації у хворих із спайковою кишковою непрохідністю до та після оперативного втручання та встановити їх вплив на розвиток ускладнень в післяопераційному періоді.

МАТЕРІАЛИ I МЕТОДИ Для досягнення поставленої мети ми дослідили 57 хворих із гострою спайковою кишковою непрохідністю. Усім пацієнтам проведено оперативне лікування разом із комплексом консервативної терапії згідно з протоколами надання медичної допомоги, затверджених МО3 України. 26 хворих прооперовано лапароскопічно, 31 - виконано лапаротомію із подальшою ліквідацією непрохідності. Під час лапароскопії у 23 пацієнтів проведено адгезіолізис із дренуванням черевної порожнини, у 3 - проведено, окрім адгезіолізису, ліквідацію інвагінації, резекцію девертикула Меккеля та ліквідацію завороту тонкої кишки. Відкрите оперативне втручання полягало в 20 хворих у роз'єднанні спайок, відновленні прохідності кишки та дренуванні черевної порожнини, в 1 хворого додатково проведено інтубацію тонкої кишки, ще в одного - резекцію пасма великого сальника, у 8 -у зв'язку із вираженими змінами стінки кишки проведено резекцію кишки із накладанням первинного ентероентероанастомозу, в одного пацієнта оперативне втручання завершене ентеростомією. Залежно від тяжкості перебігу захворювання, обстежені групи поділили на окремі підгрупи. Так, до групи хворих, оперованих лапароскопічно, увійшло 9 пацієнтів із компенсованою кишковою непрохідністю та 17 хворих із захворюванням у стадії субкомпенсації. В групі хворих, оперованих відкритим способом, було 4 пацієнтів у стадії компенсації, 19 хворих - у стадії субкомпенсації та 8 - із некомпенсованою кишковою непрохідністю.

Як маркери ендогенної інтоксикації визначали еритроцитарний індекс інтоксикації (EII) та рівень у крові середньомолекулярних пептидів за Н. І. Габріелян при довжині хвилі спектрофотометра 254 та 280 нм (СМП254, СМП 280). Дослідження проводили перед оперативним втручанням та на 3 добу після операції. Контрольну групу склали 34 практично здорових обстежених.

На основі загальноклінічних лабораторних обстежень, ультразвукового обстеження та клінічної картини ми оцінювали порушення функціональної активності внутрішніх органів (печінки, нирок, серця, легень, підшлункової залози та ін.), зміни в системі гемостазу та у складі крові після оперативного втручання. Оцінювали у роботі також час відновлення моторної фрункції кишечника.

Статистичну обробку отриманих результатів проводили за допомогою статистичних функцій программ Microsoft Office Excel 2007 та STATISTICA 8.0 на персо- 
нальному комп'ютері, застосовуючи параметричні та непараметричні методи статистичного аналізу. Первинну обробку отриманих даних проводили методами описової статистики з поданням результатів для кількісних ознак у вигляді: кількості спостережень (n), середньої арифрметичної (М), стандартної помилки середньої величини (m). Вірогідність відхилення двох рядів значень обчислювали з використання t-тесту Стьюдента для незалежних величин. Оцінку взаємозв'язку між окремими цифровими рядами здійснювали за допомогою рангової кореляції Спірмана (R). Взаємозв'язок між цифровими і нецифровими рядами оцінювали за допомогою однофакторного дисперсійного аналізу ANOVA. Критичне значення рівня значущості (р) брали $\leq 5 \%$.

РЕЗУЛЬТАТИ ДОСЛІДЖЕНЬ ТА ЇХ ОБГОВОРЕННЯ Аналіз результатів визначення рівня маркерів ендогенної інтоксикації у хворих із спайковою кишковою непрохідністю до оперативного втручання встановив різке достовірне зростання рівня СМП та значення еритроцитарного індексу інтоксикації порівняно з показниками здорових осіб ( $<0,05)$. Так, у групі хворих, яких оперували лапароскопічно, рівень СМП 254 зріс на $29 \%$, рівень СМП 280 - на 56 \%, а значення EII зросло на 54 \%. Насамперед, значення досліджуваних показників залежали від тяжкості та стадії розвитку кишкової непрохідності. Так, рівень маркерів СМП у II стадії (субкомпенсації) розвитку кишкової непрохідності був достовірно вищим за значення у початковій стадії (компенсації) патологічного процесу $(p<0,05)$ (рис. 1). Це ж стосується і значень Ell. Так, у стадії компенсації цей показник становив $(36,07 \pm 1,51)$ ум. од., а у стадії субкомпенсації - $(46,85 \pm 1,41)$ ум. од. Причинами цього зростання $€$ звичайно збільшення проникності кишкової стінки, підвищення рівня в крові біологічно активних речовин у відповідь на больовий синдром та запальний процес, ішемія та порушення мікроциркуляції, пришвидшення процесів катаболізму та ін.

Більш високі цисрри рівня маркерів ендогенної інтоксикації виявлено у хворих, яким в подальшому проводили відкриті оперативні втручання. Так, рівень СМП 254 у них перевищував значення здорових осіб на $99 \%$, рівень СМП 280 - на 235 \%, а значення EII - на 134 \%. Такі високі значення, порівняно з попередньою групою хворих, пояснюються більшою кількістю хворих із тяжким перебігом кишкової непрохідності. Це підтверджується дослідженням показників залежно від стадії перебігу патологічного процесу. Так, рівні СМП були достовірно вищі у хворих в стадії декомпенсації (перитоніту) і значно нижчі на початковій стадії кишкової непрохідності (рис. 2). Також значення EII, порівняно зі стадією компенсації, були вищими на 20 \% у хворих в стадії субкомпенсації, та на $50 \%$ у стадії декомпенсації $(p<0,05)$.

Значення показників ендогенної інтоксикації на 3 добу після оперативного втручання були достовірно вищими за значення у здорових осіб як після лапароскопічних,

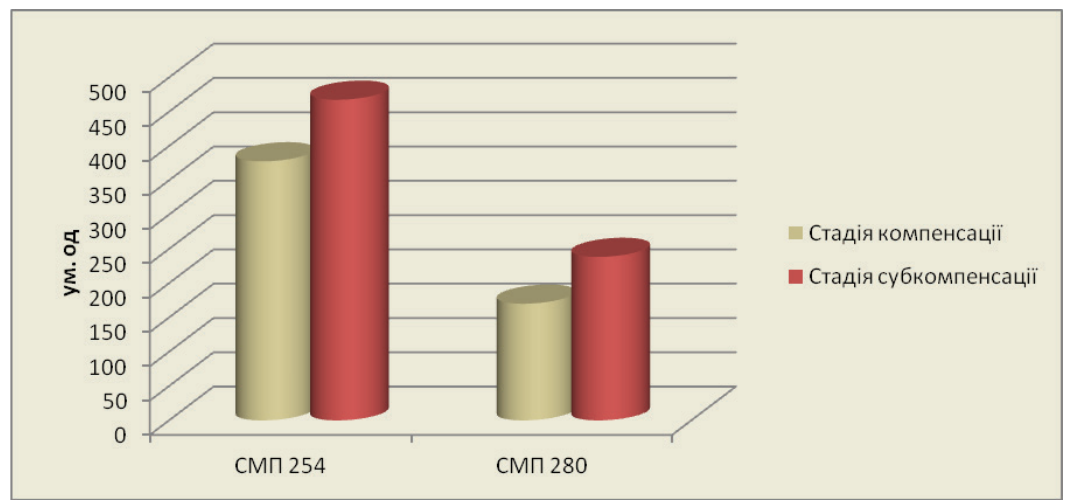

Рис. 1. Рівень середньомолекулярних пептидів у крові хворих перед лапароскопічним оперативним втручанням 3 приводу спайкової кишкової непрохідності залежно від стадії патологічного процесу.

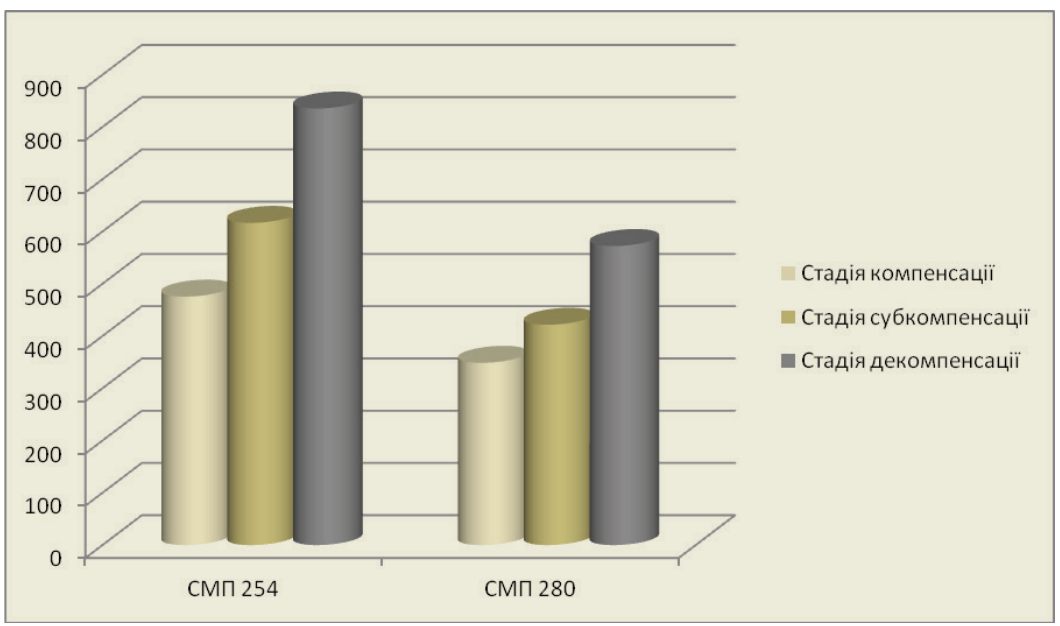

Рис. 2. Рівень середньомолекулярних пептидів у крові хворих перед відкритими оперативними втручаннями з приводу спайкової кишкової непрохідності залежно від стадії патологічного процесу. 
так і після відкритих оперативних втручань $(p<0,05)$. Після проведення лапароскопічного адгезіолізису значення показників рівня СМП 254 і СМП 280 достовірно не відрізнялись від значень до оперативного втручання $(p<0,05)$ і лише виявлено зниження EII на 12 \% $(p=0,03)$. При цьому в хворих у стадії компенсації відсутня достовірно відмінність між показниками до та після операції, тоді як при субкомпенсованій кишковій непрохідності виявлено достовірне зниження як показника EII ( $p=0,024)$, так і СMП $254(p=0,034)$.

Після відкритих оперативних втручань також встановлено достовірно вищі показники ендогенної інтоксикації порівняно з групою здорових осіб $(p<0,05)$. При цьому, як і в попередній групі обстежених, значення маркерів інтоксикації достовірно не відрізнялись від показників перед оперативним втручанням. Достовірну відсутність змін виявлено й аналізуючи показники відповідно до стадії перебігу захворювання.

Відсутність значного зниження рівня ендогенної інтоксикації після оперативного втручання на тлі дезінтоксикаційної терапії ймовірно пов'язано із тим, що окрім основного захворювання, має значення ендогенна інтоксикація, спричинена оперативним втручанням (травма тканин, використання засобів для наркозу, післяопераційний парез кишечника, стимуляція катаболізму із розпадом білків, транслокація мікроорганізмів тощо).

Аналіз розвитку ускладнень у післяопераційний період поданий у таблиці 1. Серед ускладнень переважали порушення фрункції печінки та нирок, гіперкоагуляція та гіпопротеїнемія. Саме із цими порушеннями часто пов'язують розвиток поліорганної недостатності та тяжкі ускладнення, такі, як недостатність швів анастомозу, септичні процеси та ін.

Аналіз залежності наявності ускладнень у післяопераційному періоді та рівня показників ендогенної інтоксикації, який проводили за допомогою однофакторного дисперсійного аналізу, показав досить несподівані результати. У більшості хворих відсутній достовірний зв'язок між наявністю ускладнень і тяжкістю ендогенної інтоксикації. Лише у хворих після лапароскопічної ліквідації непрохідності, які оперовані на початковій (компенсації) стадії захворювання, виявлено достовірний прямий зв'язок між наявністю ускладнень і рівнем СМП 254, СМП 280 та ElI після оперативного втручання (рис. 3).

Дані, які ми отримали, дещо дивують, тому що розвиток ускладнень та поліорганну недостатність більшість авторів пов'язує напряму із рівнем ендогенної інтоксикації. Ймовірно, що у розвитку порушень фрункцій внутрішніх органів та системи гомеостазу після операції ключову роль відіграє не власне ендогенна інтоксикація, а порушення мікроциркуляції, гіпоксія, зростання у крові медіаторів запалення та ін.

Недивлячись на те, що печінка повинна першою ушкоджуватись при токсемії, ми виявили лише достовірну залежність між рівнем СМП 254 до оперативного втручання та порушенням функції печінки у хворих із

Таблиця 1. Розвиток ускладнень у хворих після операції з приводу спайкової кишкової непрохідності

\begin{tabular}{|l|c|c|}
\hline \multirow{2}{*}{\multicolumn{1}{|c|}{ Ускладнення }} & \multicolumn{2}{|c|}{ Кількість хворих } \\
\cline { 2 - 3 } & оперовані лапароскопічно & оперовані відкритим способом \\
\hline Рецидив непрохідності & 2 & 0 \\
\hline Нагноєння післяопераційної рани & 0 & 8 \\
\hline Порушення функції печінки & 7 & 13 \\
\hline Порушення функції нирок & 3 & 8 \\
\hline Анемія & 0 & 1 \\
\hline Гіпопротеїнемія & 3 & 2 \\
\hline Гіперпротеїнемія & 0 & 1 \\
\hline Гіперкоагуляція & 3 & 0 \\
\hline Гіпокоагуляція & 0 & 1 \\
\hline Гострий панкреатит & 1 & 2 \\
\hline Тривала гіпертермія & 0 & 1 \\
\hline Лейкоцитопенія & 0 & \\
\hline Тривалий больовий синдром & 0 & 15 \\
\hline Два і більше ускладнень & 4 & \\
\hline Відсутність ускладнень & 12 & \\
\hline
\end{tabular}
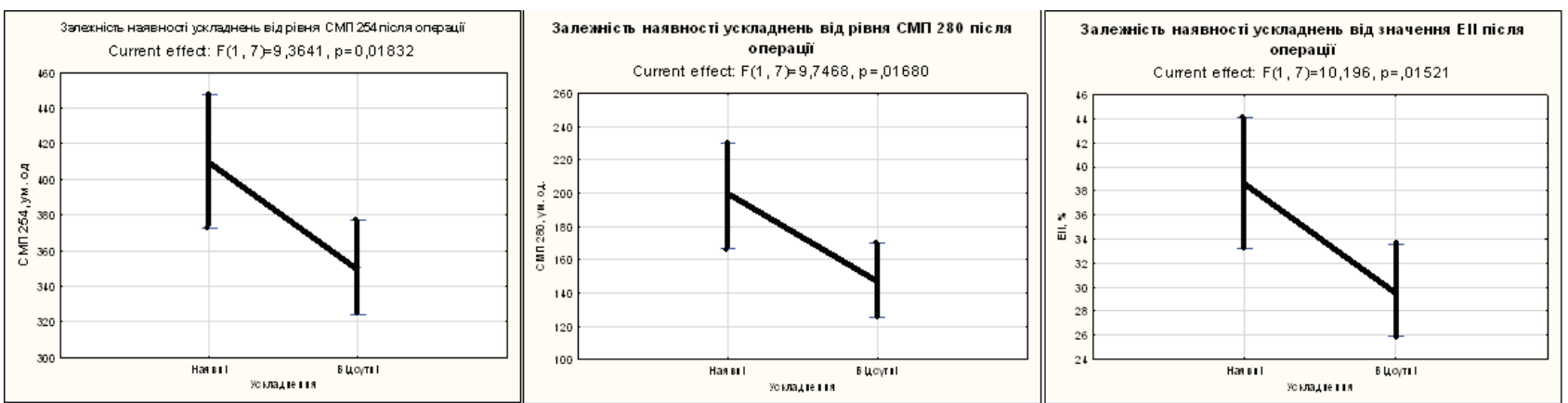

Рис. З. Залежність наявності ускладнень від рівня маркерів ендогенної інтоксикації у пацієнтів із компенсованою непрохідністю після лапароскопічного адгезіолізису (ANOVA). 
некомпенсованою кишковою непрохідністю (у стадії перитоніту) після відкритих оперативних втручань (рис. 4).

Враховуючи, що згідно з літературними даними, основним джерелом токсинів у хворих із кишковою непрохідністю $€$ вміст кишечника, підвищення проникності мембран ентероцитів та транслокація мікроорганізмів, важливим є визначення залежності між показниками ендогенної інтоксикації та часом відновлення моторної функції кишок.

Встановлено, що у пацієнтів після лапароскопічного адгезіолізису моторна функція кишок (перистальтика) відновлювалась в середньому через $(16,4 \pm 1,2)$ год після оперативного втручання. Після відкритих оперативних втручань 3 приводу кишкової непрохідності моторика кишечника відновлювалась через $(32,2 \pm 4,1)$ год. Встановлено, що незалежно від виду оперативного втручання, час відновлення перистальтики тісно корелював з усіма показниками ендогенної інтоксикації (табл. 2).

При цьому ця залежність була більш вираженою у групі хворих після лапароскопічного адгезіолізису. Це свідчить все ж таки, що кишечник відіграє провідну роль у розвитку ендогенної інтоксикації.

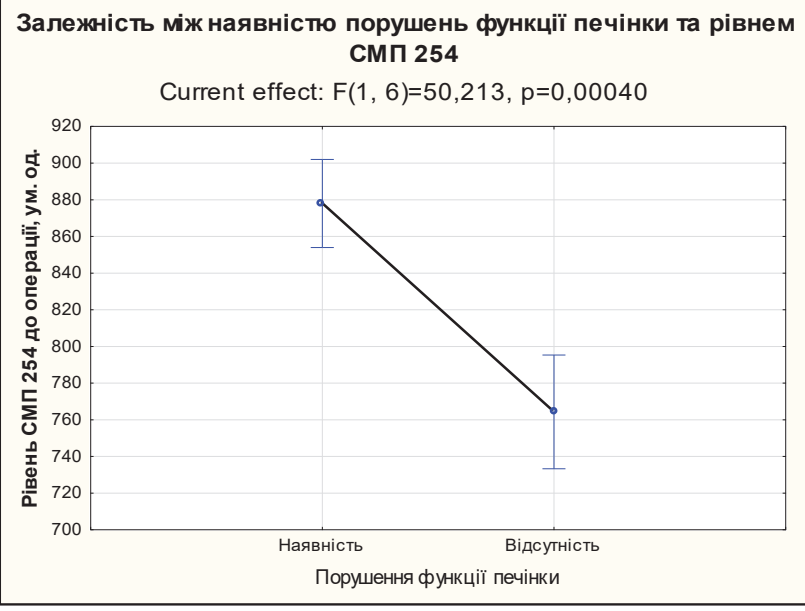

Рис. 4. Залежність між порушенням функції печінки і рівнем СМП 254 до операції у пацієнтів із декомпенсованою непрохідністю після відкритих оперативних втручань (ANOVA).

Таблиця 2. Кореляційний аналіз (Спірмана) залежності часу відновлення перистальтики від показників ендогенної інтоксикації (R)

\begin{tabular}{|l|c|c|c|c|c|c|}
\hline \multirow{2}{*}{ Група } & \multicolumn{3}{|c|}{ Показник до операції } & \multicolumn{3}{c|}{ Показник після операції } \\
\cline { 2 - 7 } & СMП 254 & СMП 280 & EII & CMП 254 & CMП 280 & EII \\
\hline Показники після лапароскопічних втручань & $0,603^{*}$ & $0,577^{*}$ & $0,536^{*}$ & $0,754^{*}$ & $0,700^{*}$ & $0,614^{*}$ \\
\hline Показники після відкритих оперативних втручань & $0,561^{*}$ & $0,365^{\star}$ & $0,411^{*}$ & $0,568^{*}$ & $0,425^{\star}$ & $0,507^{\star}$ \\
\hline
\end{tabular}

Примітка. * - достовірність залежності.

ВИСНОВКИ 1. На основі отриманих даних встановлено, що у хворих із гострою спайковою кишковою непрохідністю значно зростає рівень маркерів ендогенної інтоксикації до операції і ступінь зростання цих показників перш за все залежить від стадії перебігу кишкової непрохідності.

2. На 3 добу після операції виявлено незначне зниження рівня ендогенної інтоксикації, що свідчить про додаткові механізми розвитку токсикозу після оперативного втручання (травма тканин, використання засобів для наркозу, післяопераційний парез кишечника, стимуляція катаболізму з розпадом білків, транслокація мікроорганізмів тощо).

3. Виявлено переваги лапароскопічних методів лікування, що полягали у нижчому рівні маркерів ендогенної інтоксикації після операції, швидше відновлення перистальтики кишок та нижчий відсоток ускладнень. Хоча ці дані можуть бути пов'язані 3 менш тяжким перебігом кишкової непрохідності у цієї групи хворих.

4. Ми не встановили значного достовірного взаємозв'язку між маркерами ендогенної інтоксикації та розвитком усклад- нень у післяопераційний період, що свідчить про інші механізми фрормування дисфункції внутрішніх органів та порушень у системі гомеостазу.

5. Виявлено тісний взаємозв'язок між часом відновлення моторної фрункції кишок та рівнем ендогенної інтоксикації, що свідчить про провідну роль кишечника у формуванні токсикозу у хворих із спайковою кишковою непрохідністю.

Перспективи подальших досліджень Враховуючи результати дослідження, невстановленими є механізми розвитку ускладнень у післяопераційний період. Так, зокрема, важливим є значення стану мікроциркуляторного русла, імунної системи, рівень маркерів запалення та встановлення їх ролі у клінічному перебігу післяопераційного періоду в пацієнтів із спайковою кишковою непрохідністю. Невирішеним є питання удосконалення лікування хворих із гострою спайковою непрохідністю, особливо в післяопераційному періоді, враховуючи високий рівень маркерів ендогенної інтоксикації.

\section{СПИСОК ЛІТЕРАТУРИ}

1. Скрипко В. Д. Стан ендогенної інтоксикації та динаміка змін мікроелементного гомеостазу при експериментальній гострій тонкокишковій непрохідності / В. Д. Скрипко // Буковинський медичний вісник. - 2013. - Т. 17, № 1 (65). - С. 122-125.

2. Принципи надання хірургічної допомоги хворим на гостру спайкову непрохідність кишечника / І. А. Лурін, І. А. Тітомір, О. І. Гладишенко [та ін.] // Харківська хірургічна школа. - 2013. - № 4(61). - С. 114-116.

3. Люлько І. В. Діагностика та лікування хворих зі злуковою непрохідністю кишечника / І. В. Люлько, Е. Ф. Самарець,
В. К. Кадук // Харківська хірургічна школа. - 2004. - № 1-2. C. $48-49$

4. Павляк А. Я. Проблема ендотоксикозу при гнійному перитоніті і шляхи його корекції / А. Я. Павляк // Галиц. лікар. вісн. - 2010. - 17, № 3. - С. 172-178.

5. Стан ендогенної інтоксикації та динаміка змін клітинного складу лімфатичних вузлів при високій гострій кишковій непрохідності в експерименті / В.І.Півторак, М. П. Булько, А. В. Вознюк, В. В. Вознюк // Клінічна анатомія та оперативна хірургія. - 2010. - T. 9, № 2. - C. 40-44. 
6. Спаечная кишечная непроходимость: тактика, лечение, профилактика рецидивов / О. И. Дубровщик, Г. Г. Мармыш, И. С. Довнар [и др.] // Журнал Гродненского государственного медицинского университета. - 2012. - № 2. - С. 20-23
7. Чекмазов И. А. Спаечная болезнь брюшины / И. А. Чекмазов. - M., 2008. - C. 57-60.

\author{
(C). V. Bukata
}

I. Horbachevsky Ternopil State Medical University

\title{
ENDOGENOUS INTOXICATION INFLUENCE ON THE DEVELOPMENT OF COMPLICATIONS AFTER TREATMENT OF OPERATIONAL ADHESIVE INTESTINAL OBSTRUCTION
}

Summary. The problem of acute adhesive intestinal obstruction remains one of the most urgent and complicated in modern abdominal surgery. Among all types of obstruction, adhesive obstruction of the intestine occurs most often and ranges from 40.4 to $86 \%$ of cases.

The aim of the study - to assess the level of endogenous intoxication in patients with adhesive obstruction before and after surgery and determine their effect on the development of complications in the postoperative period.

Materials and Methods. The article adduces the results of an examination of 57 patients with acute adhesive intestinal obstruction. Among them 26 patients were operated laparoscopically, in 31 - laparotomy was performed, followed by the elimination of obstruction. The study of the level of endogenous intoxication markers (mediumsmolecular peptides and determination of the erythrocytic index of intoxication) was performed prior to the operation and at the $3^{\text {rd }}$ day of postoperative period.

Results and Discussion. It has been established that in patients with acute adhesive obstruction, the level of markers of endogenous intoxication significantly increases to the operation and the degree of growth of these indicators primarily depends on the stage of intestinal obstruction. In 3 days after the surgery, a slight decrease in the level of endogenous intoxication was revealed, indicating additional mechanisms of development of toxicosis after surgery.

Conclusions. During the study, we did not establish a significantly reliable relationship between markers of endogenous intoxication and the development of complications in the postoperative period. A close correlation was found between the time of recovery of the motor function of the intestines and the level of endogenous intoxication, which indicates the leading role of the intestine in the formation of toxicosis in patients with adhesive intestinal obstruction.

Key words: acute adhesive intestinal obstruction; endogenous intoxication; complication; postoperative period.

CB. В. Буката

ГВУз “Тернопольский государственный медицинский университет имени И. Я. Горбачевского”

ВЛИЯНИЕ ЭНДОГЕННОЙ ИНТОКСИКАЦИИ НА РАЗВИТИЕ ОСЛОЖНЕНИЙ ПОСЛЕ ОПЕРАТИВНОГО ЛЕЧЕНИЯ БОЛЬНЫХ С СПАЕЧНОЙ КИШЕЧНОЙ НЕПРОХОДИМОСТЬЮ

Резюме. Проблема острой спаечной кишечной непроходимости остается одной из наиболее актуальных и сложных в современной абдоминальной хирургии. Среди всех видов непроходимости спаечная непроходимость кишечника встречается чаще всего и составляет от 40,4 до 86 \% случаев.

Цель исследования - оценить уровень показателей эндогенной интоксикации у больных со спаечной кишечной непроходимостью до и после оперативного вмешательства и установить их влияние на развитие осложнений в послеоперационном периоде.

Материалы и методы. В статье отражены результаты обследования 57 больных с острой спаечной кишечной непроходимостью. Из них 26 пациентов прооперированы лапароскопически, 31 - выполнена лапаротомия с последующей ликвидацией непроходимости. Проведено исследование уровня маркеров эндогенной интоксикации (среднемолекулярных пептидов и определения эритроцитарного индекса интоксикации) до операции и на 3 сутки послеоперационного периода.

Результаты исследований и их обсуждение. Установлено, что у больных с острой спаечной кишечной непроходимостью значительно возрастает уровень маркеров эндогенной интоксикации до операции и степень роста этих показателей прежде всего зависит от стадии течения кишечной непроходимости. На 3 сутки после операции выявлено незначительное снижение уровня эндогенной интоксикации, что свидетельствует о дополнительных механизмах развития токсикоза после оперативного вмешательства.

Выводы. В течение исследования нами не установлено значительной достоверной взаимосвязи между маркерами эндогенной интоксикации и развитием осложнений в послеоперационный период. Выявлена тесная взаимосвязь между временем восстановления моторной функции кишечника и уровнем эндогенной интоксикации, что свидетельствует о ведущей роли кишечника в фрормировании токсикоза у пациентов со спаечной кишечной непроходимостью.

Ключевые слова: острая спаечная кишечная непроходимость; эндогенная интоксикация; осложнения; послеоперационный период. 